\title{
Review on Assesment of Permeability of Enhancement Property of Hyaluronic Acid as Compare to Peg in Core Gel Liposome
}

\author{
Sangeeta Sinku1*, Gaurav Kumar Sharma², Rahul Singh Kushwaha1, Dr. Kaushal K. Chandrul ${ }^{3}$ \\ 1Pharmacy Graduate, ${ }^{2}$ Research Scholar and Assistant Professor, ${ }^{3}$ Principal \\ 1,2,3Faculty of Pharmaceutical Sciences, Mewar University, Chittorgarh, Rajasthan, India
}

\begin{abstract}
How to cite this paper: Sangeeta Sinku | Gaurav Kumar Sharma | Rahul Singh Kushwaha | Dr. Kaushal K. Chandrul "Review on Assesment of Permeability of Enhancement Property of Hyaluronic Acid as Compare to Peg in Core Gel Liposome" Published in International Journal of Trend in Scientific Research and Development (ijtsrd), ISSN: 24566470, Volume-3 | Issue-4, June 2019, pp.585-596, URL: https://www.ijtsrd.c om/papers/ijtsrd23 313.pdf

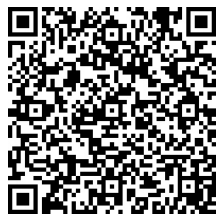

IITSRD23313
\end{abstract}

Copyright (C) 2019 by author(s) and International Journal of Trend in Scientific Research and Development Journal. This is an Open Access article distributed under the terms of the Creative Commons

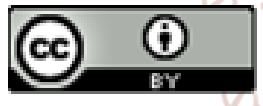
Attribution License (CC BY 4.0) (http://creativecommons.org/licenses/ by/4.0)

of physicochemical properties. Also skin barrier properties can change significantly based on age, race, location of application etc[1]. Since the primary FDA endorsement of a transdermal pharmaceutical item in 1979, transdermal medicate conveyance frameworks have pulled in the consideration of the detailing researchers [2]. Usually since sedate conveyance to skin incorporates a wide cluster of helpful innovations and pharmaceutical applications and the transdermal course can offer more focal points compared with the verbal and parenteral routes of drug organization[3]. To overcome the confinement a few procedures have been presented which run from utilizing entrance enhancers to assist the drug penetrate into the skin by tweaking. The obstruction work of the stratum corneum sc to physically by passing the sc utilizing procedures such as microneedles laser removal etc. Benefits of near by conveyance are legitimately archived which incorporates focused on conveyance, lower systemic presentation and lower harmfulness than verbal drugs. Preferences of topical medicate conveyance over verbal conveyance incorporate, quick onset of activity and Sedate input can be halted at any point after expulsion of the fix from the location[4]. Gives unfaltering plasma levels. Makes strides bioavailability and approaches to entrance improvement have been created to overcome these challenges. Best route for pediatrics patients. Suitable route for unconsious or vomiting patient. Lesser chances of overdose and simple discovery of medicate.

Classic physical infiltration upgrade methodologies incorporate iontophoresis[5], sonophoresis [6], penetration enhancers[7] and vesicular medicate conveyance frameworks [8-9]. Electroporation[10], phonophoresis [1113] or supersaturated arrangements[14-15], but as of late novel approaches have been created such as compressed gas drive[16] and the utilize of microfabricated microneedles to puncture the stratum corneum, laser removal etc[17]. Among these conveyance modules, the vesicular frameworks are possibly useful as vesicles tend to fuze and follow to the cell surface; usually accepted to extend the thermodynamic movement angle of the sedate at vesicle stratum corneum interface hence driving to improved penetration rate [7]. A few chemical substances have been appeared to have the capacity to upgrade penetration over the skin, and are hence commonly included in transdermal frameworks. These incorporate moo atomic weight alcohols [18] alkyl methanol sulphoxides [19] non ionic surfactants [20] (polysorbates, polyethoxylated alkyl ethers and esters and poloxamers), 
oleic corrosive in collaboration with propylene glycol [2122] and azone [23-24]. And planning, characterizing different phospholipid, vesicles to be specific liposomes, ethosomes, propylene glycol (PG)-liposomes, ethosomes, transferosomes and hyaluosomes. The liposomes and ethosomes are not elective to each other. Their whole physicochemical properties and sedate penetrability components are very diverse from each other [8-9]. Broad investigate has been done on the application in TDDS of liposomes and ethosomes. Routine liposomes cannot enter into profound layers of the skin, but they can adsorb on the upper layer of the SC. The reason being, customary liposomes are less deformable, get dried out totally, fuze and limited to the skin surface [25]. Liposomes don't have capacity to penetrate the phycocyanin into the profound layers of the skin and embodiment productivity of liposomes was found less than $50 \%$ [26]. To overcome the destitute penetrability of liposomes through the skin, ethosomes were to begin with created for transdermal conveyance by Elka Touitou. Ethosomes are delicate liable vesicles implanted with tall alcoholic substance (up to $45 \% \mathrm{v} / \mathrm{v}$ ). The ethosomal molecule estimate was exceptionally moo compared to liposomes due to the interpenetration of lipid bilayers. It is proposed that synergetic movement of lipid and ethanol alter the warm properties of stratum corneum by fluidization[24]. They detailed that ethosomes kept up the skin fluidized situation by interaction with hydrophilic portions of lipids within the SC[28]. The polysorbate 80 and turpentine was utilized as the saturation enhancers for the liposomes and ethosomes, separately. The turpentine contained ethosomes appeared higher skin penetration after $24 \mathrm{~h}$ compared to liposomes separately .To kill these side impacts, transdermal course can be chosen for organization. Among these physicochemical criteria are appropriate atomic estimate and ideal medicate lipophilicity in arrange to pick upget to through the greatly lipophilic stratum corneum boundary[3]. Over the past three decades, lipidbased nano-sized vesicles have been utilized effectively for transdermal medicate conveyance frameworks; these nanosized conveyance frameworks incorporate liposomes, ethosomes and transferosomes have been utilized for hydrophilic and lipophilic sedate conveyance over the skin obstructions[29]. Numerous reports have pointed out that not all lipid-based vesicles are similarly competent of accomplishing adequately tall and steady penetrability through the impressive obstructions of the skin. For illustration, transferosomes and ethosomes epitomizing edge activators and certain sum of liquor individually illustrated predominant skin penetrability compared with ordinary liposomes[30]. While the writing has barely said how these fluid liposomal scatterings might conceivably follow to the skin surface to permit adequate time for medicate saturation over the skin. On the drawback, these non ordinary liposomes might have dejected rheological characteristics and adherence to the skin. This conceivably requires the utilize of extra gooey vehicle or joining of the liposomal frameworks into suitable patches for the ease of application and spreading the managed dosage on the skin. More as of late, gel core-filled liposomes have been utilized viably for transdermal medicate conveyance of little and macromolecules such as curcumin and hyaluronic corrosive[31-32]. These novel liposomes are composed of phospholipid vesicles entrapping gel material in their core. Therefore, they can combine the advantages of liposomes and gel formulations in one drug delivery system[33]. The following section will focus on structure of the skin and understanding the role of core gel liposomes after liposomes in the grand theme of drug delivery to the skin.

\section{SKIN}

\subsection{Human skin: penetration barrier}

Skin is the biggest organ of the human body weighing at approximately $10 \%$ of the body weight in adults and with an impressive surface region of around $20,000 \mathrm{~cm}^{2}$ [34]. the essential work of the skin is to preserve the body hydration[35]. Skin forms a vital obstruction between the environment and our organs. This barrier function protects us from hurtful impacts of chemicals, microorganisms, allergens and UV radiation. Skin barrier is $100-10,000$ times less penetrable compared to a blood capillary divider[36]. Other major functions of the skin include homeostasis by thermoregulation and sensory function by detecting heat, pressure, pain and allergen mediated stimuli. Thickness of skin shift between $0.5-4 \mathrm{~mm}$ depending upon the anatomical location, which subsequently means based on the location, skin barrier can also vary considerably.

Briefly, skin can be considered to be divided in four layers, outermost stratum corneum (non-viable epidermis), viable epidermis, dermis, and bottom most subcutaneous tissue. Apart from different layers, skin also contains appendages like hair follicles sweat organs and sebaceous glands.(Figure1)

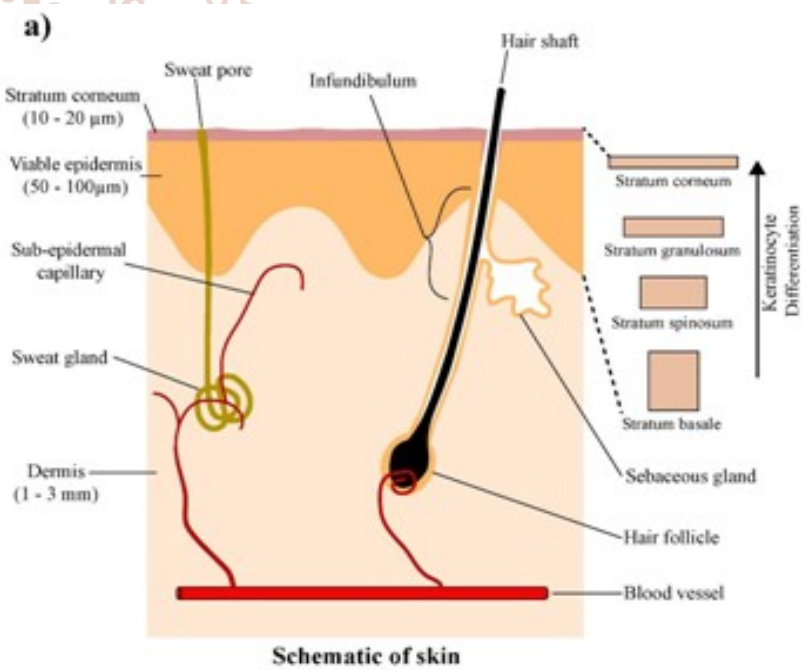

Figure:- 1Shows a schematic representation of the human skin.

\subsubsection{Stratum corneum (SC):-}

The exposed layer of the skin (also termed as horny layer) which is approximately $10 \mathrm{~mm}$ thick and formed by $10-15$ layers of highly flattened, highly differentiated, nonnucleated cells called corneocytes. It has barrier property due to presence of $79-90 \%$ of protein and $5-15 \%$ of lipids. The multilayered epidermis shifts in thickness which basically depends upon cell thickness and layers of epidermis, body site, age, gender and race[36]. it is well built up that the SC is responsible for a major fraction of the boundary to the percutaneous retention of topically applied compounds. . A strong evidence for this was given within the shape of increased transdermal flux for different penetrating compounds when the SC was physically removed by tape stripping[37-42]. Removal of the SC can increase transdermal permeability by a factor of $10-20$ [34]. Although SC is the major skin barrier, deeper layers also possess a small barrier function. 


\subsubsection{Viable epidermis}

Viable epidermis is the layer directly below SC and is mindful for producing the highly differentiated corneocytes of the SC. Viable epidermis is typically $50-100 \mu \mathrm{m}$ thick and contains three distinct layers based on the state differentiation of keratinocytes. Apart from keratinocytes viable epidermis moreover contains Langerhans cells responsible for immune response, melanocytes which produce melanin and Merkel cells which are involved in the somato sensory functions[43]. Viable epidermis does not contain any blood capillaries but does contain nerve fibers[44]. Due to a lack of vascular network, nutrients are delivered to the keratinocytes by inactive is semination through the interstitial liquid.

\subsubsection{Hypodermis}

It holds the fat tissues and acts as a back memberane for both epidermial and dermal layer of skin. It has its claim significance in transdermal medicate conveyance. Sedate might enter through all three layers to reach systemic circulation[45].

\subsubsection{Dermis}

Thickness of this layer is 3-5 $\mathrm{mm}$. It mainly consist of connective tissues obligatory in direction of body temperature, oxygen supplements to the skin and evacuating poisonous items[45]. Dermis is divided in to outer papillary dermis and inner reticular dermis. A large proportion of the dermis by weight contains a relatively loose fibrous connective tissue matrix. Cellular component of the dermis comprises of fibroblasts, epithelial cells, mast cells and cells of immune system such as lymphocytes and leukocytes. Dermis also provides physical support for skin appendages, nerve fibers and network of lymphatic and blood vessels. Microvasculature of the dermis is responsible for maintaining the sink conditions for the drug molecules that have penetrated through the primary skin barrier into the dermis[47]. Dermis does not posture as a major barrier to drugs unless drugs are susceptible to enzymatic degradation then dermis can pose as a relevant barrier for absorption of drugs into systemic circulation.

\subsubsection{Skin appendages}

Most important skin appendages include, sweat organs, hair follicles and sebaceous glands. These appendages originate from lower dermis and reach the skin surface by penetrating through viable epidermis and the stratum corneum. Skin appendages occupy about $0.1 \%$ of the total skin area[48]. Amongst all appendages sweat glands are the most abundant with approximately 400 glands $/ \mathrm{cm}^{2}$ [34]. Hair follicles are the second most abundant skin appendages. Entire human body is covered with hair follicles except on the palms and soles. Due to secretion of sweat, $\mathrm{pH}$ of the skin surface is mildly acidic and can be in the range of $4-7.0$ [49]. As variation in $\mathrm{pH}$ could affect the stability of the formulation or even irritate the skin. Hair follicles are related with one or more sebaceous organs towards the mouth of the hair follicles. Sebaceous glands are holocrine glands which secrete an oily fluid called sebum.. Sebum typically is composed of mixtures of triglycerides free greasy acids squalene, squalene and waxes. Excretion rate of sebum averages around $0.1 \mathrm{mg} / \mathrm{cm}^{2} / \mathrm{h}[50]$. It is a common consensus that sebum does not have a skin barrier function. However, it may have a beneficiary or a retarding effect on the percutaneous penetration of the drug applied to the skin, depending on the nature of formulation and physicochemical properties of the sedate.

\section{TRANSDERMAL DRUG DELIVERY SYSTEM}

Among all strategies utilized for discharging drugs in a controlled way into the human body, transdermal sedate conveyance (TDD) is presently broadly recognized as one of the foremost promising ones, with a expansive number of commercialized applications. The foremost common transdermal frameworks display on the advertise are based on semi-permeable films (the so-called "patches). Transdermal medicate conveyance medications final a few hours a day, since they are regularly required to preserve a consistent concentration of medicate in blood. As a result, an perfect TDD framework ought to be compact and versatile. The TDD framework combines created parts with a commercially accessible micromotor and changeless magnets.

\section{FACTORS AFFECTING TRANSDERMAL DRUD DELIVERY}

\subsection{Physiochemical properties of active moiety[51-52]}

\subsubsection{Partition coefficient}

Medicate have both water and lipid solvency. Perfect segment coefficient for middle transdermal conveyance is $\log \mathrm{K} 1-3$. For exceedingly lipophillic medicate (log k43), intracellular course is positive, while for hydrophillic drugs ( $\log \mathrm{k} 51$ ), it is saturated by means of transcellular course.

\subsubsection{Molecular size}

Atomic measure of the medicate is inversaly corresponding to transdermal flux. The perfect atomic estimate of sedate atom for transdermal conveyance is 400 .

\subsubsection{Solubility/melting point}

Most natural solutes have tall dissolving point and moo dissolvability at ordinary temperature and weight. Lipophillic sedate penetrates speedier than hydrophillic substances, but it ought to more over have watery dissolvability as required in most of topical definitions.

\subsubsection{Ionization}

Unionized drug permeates the skin as according to $\mathrm{pH}$ Partition hypothesis.

\subsubsection{Diffusion coefficient}

Entrance of sedate depends on dissemination coefficient of medicate. At a steady temperature, the dissemination coefficient of medicate basically depends on properties of medicate, dissemination medium and their interaction.

\subsection{Physiochemical properties of the drug delivery system[53-54]}

\subsubsection{Release characteristics}

Medicate discharge instrument primarily depends on medicate atoms which are broken up or suspended within the conveyance framework and on interfacial segment coefficient or $\mathrm{pH}$ of the sedate from conveyance framework to the skin tissue. On the off chance that the medicate is effectively discharged from the conveyance framework, the rate of transdermal saturation will be higher.

\subsubsection{Composition of drug delivery system}

Composition may not influence discharge properties but may influence its penetrability usefulness. For case, methyl salicylate is more lippophilic than parent corrosive, i.e. salicylic corrosive, and its percutaneous retention is tall when connected to skin in a lipoidal vehicle. 


\subsubsection{Enhancement of transdermal permeation}

Lion's share of drugs will not saturate into skin for theraputic utilize. A few enhancers are utilized for synergistic activity without showings its properties (e.g. dimethyl sulphoxide, acetone, propylene glycol and tetradihydrofuryl liquor).

\subsection{Physiological properties[55-56]}

Skin obstruction properties within the neonate and youthful newborn child the skin surface of the infant is marginally hydrophobic, generally dry and unpleasant when compared to that of more seasoned newborn children. Stratum corneum hydration stabilizes by the age of 3 months. Skin boundary properties in matured skin. There are a few changes within the physiology of matured skin (465 a long time). The moisture content of human skin diminishes with age. There's a pulverization of the epidermal intersection and thus, the region accessible for transmission into the dermis is reduced.

\subsubsection{Race}

Racial contrasts between dark and white skins have appeared a few anatomical and physiological capacities of the skin. In dark skin, there's expanded intracellular saturation due to higher lipid substance and higher electrical skin resistance levels when compared to whites, but this contrast isn't identified in stripped skin.

\subsubsection{Skin temperature}

The human body maintains a temperature of $32-37^{\circ} \mathrm{C}$ across the skin. Hence, increase in temperature leads to increase in diffusion through the tissue.

\section{TYPES OF TRANSDERMAL DRUG DELIVERY}

\begin{tabular}{|c|c|c|c|}
\hline Formulation & Mechanism & Conclusion & Reference \\
\hline Liposomes & $\begin{array}{l}\text { Permeation enhancer effect } \\
\text { and direct vesicle fusion with } \\
\text { stratum corneum }\end{array}$ & $\begin{array}{l}\text { Ability to modulate drug delivery } \\
\text { without toxicity and makes the two } \\
\text { vesicles useful to formulate topical } \\
\text { route. }\end{array}$ & [114] \\
\hline $\begin{array}{c}\text { Cationic } \\
\text { Transferosomes }\end{array}$ & $\begin{array}{l}\text { Inducing strong humoral and } \\
\text { cellular immune response }\end{array}$ & $\begin{array}{l}\text { Inducing strong humoral and } \\
\text { cellular immune response }\end{array}$ & [115] \\
\hline Ethosomes & $\begin{array}{l}\text { Lipid perturbation and } \\
\text { increasing the intercellular } \mathrm{SC} \\
\text { lipid lamellae space of } \\
\text { stratum corneum }\end{array}$ & $\begin{array}{l}\text { Lipid perturbation along with } \\
\text { elasticity of ethosomes vesicle } \\
\text { seems to be the main contributor for } \\
\text { improved skin permeation }\end{array}$ & [116] \\
\hline Invasomes & $\begin{array}{l}\text { Synergistic effect of liposomes, } \\
\text { terpenes and ethanol of Trend }\end{array}$ & $\begin{array}{l}\text { Invasomes containing } 1 \% \text { of } \\
\text { terpenes mixture present an } \\
\text { effective drug carrier system for } \\
\text { delivering the highly hydrophobic } \\
\text { drug Temoporfin into the stratum } \\
\text { corneum and deeper layers of skin. }\end{array}$ & \\
\hline Niosomes & $\begin{array}{l}\text { No absorption due to large } \mathrm{SN}: 2 \\
\text { molecular structure of } \\
\text { Gallidermin as well as the } \\
\text { large niosomal structure }\end{array}$ & $\begin{array}{l}\text { Gallidermin loaded in anionic } \\
\text { niosomes and incorporated in gel is } \\
\text { the superior topical anti-bacterial } \\
\text { formulation because of high } \\
\text { accumulation in the skin with no } \\
\text { risk of systemic effect. }\end{array}$ & {$[117]$} \\
\hline $\begin{array}{c}\text { Deformable } \\
\text { liposomes }\end{array}$ & $\begin{array}{l}\text { By transcutaneous hydration } \\
\text { Force }\end{array}$ & $\begin{array}{l}\text { Deformable liposomes improve in } \\
\text { vitro skin delivery compared to } \\
\text { either aqueous solution or normal } \\
\text { liposomes. }\end{array}$ & [118] \\
\hline Ethosomes & $\begin{array}{l}\text { Increase in thermodynamic } \\
\text { activity due to evaporation of } \\
\text { ethanol, increases penetration } \\
\text { of drug molecule due to } \\
\text { reduction in barrier property } \\
\text { of stratum corneum by } \\
\text { ethanol. }\end{array}$ & $\begin{array}{l}\text { Ethosomes bearing melatonin } \\
\text { offered a suitable approach for } \\
\text { transdermal delivery when } \\
\text { compared to liposomes and } \\
\text { hydroethanolic solution. }\end{array}$ & [119] \\
\hline $\begin{array}{c}\text { Elastic } \\
\text { liposome }\end{array}$ & $\begin{array}{l}\text { IL-13 antisense } \\
\text { oligonucleotide (ASO) was } \\
\text { designed and formulated with } \\
\text { cationic elastic liposome (cEL) }\end{array}$ & $\begin{array}{l}\text { IL-13 ASO/cEL-treated AD mice } \\
\text { showed reduced infiltration of } \\
\text { inflammatory cells into the } \\
\text { epidermal and dermal areas, with } \\
\text { concomitant reduction of skin } \\
\text { thickness. }\end{array}$ & {$[120]$} \\
\hline $\begin{array}{c}\text { SPACE } \\
\text { ethosome }\end{array}$ & $\begin{array}{l}\text { The peptide was conjugated to } \\
\text { phospholipids and used to } \\
\text { prepare an ethosomal carrier } \\
\text { system (_110 nm diameter), } \\
\text { encapsulating HA (200- } 325 \\
\text { kDa) }\end{array}$ & $\begin{array}{l}\text { Concentrations of HA in skin were } \\
1000 \text {-fold higher than those in } \\
\text { blood; confirming the localized } \\
\text { nature of HA delivery into skin. The } \\
\text { SPACE ethosomal delivery system } \\
\text { provides a formulation for topical } \\
\text { delivery of macromolecules. }\end{array}$ & [121] \\
\hline
\end{tabular}

Table:-1 Types of Transdermal delivery system 


\subsection{LIPOSOMES}

Liposomes are an alluring candidate as pharmaceutical novel nanocarriers that have as of now been utilized clinically[5758]. Liposomes have been extensively used as carriers for hydrophilic drugs for many reasons. First, they can protect the core-incorporated hydrophilic drug from degradation. Second, they aid this kind of drugs in crossing several biological membranes. Finally, they are sought of amongst the safest types of drug delivery systems due to their high biocompatibility and biodegradability properties originating from their main components which are the phospholipids vesicles bilayered structures. The advancement of sterically stabilized liposomes that decrease the location and ensuing take-up of the liposomes by the resistant framework, presently appears to have satisfied the requests of a long circulating medicate conveyance framework[59-62].Within the field of topical vehicles for dermal/transdermal conveyance ultra adaptable liposomes are frequently considered the vehicle of choice basically since of their tall performance as transdermal penetration enhancers and their good stability in suspension [63-68]. It is composed by a blend of lipids with moo stage move temperatures and an fitting sum of a cleanser. The cleanser acts as a film destabilizer creating an increment in layer deformability. Its tall deformability has been proposed to be the cause of their capacity to enter the skin and indeed permit for proteins to reach systemic circulation [69-75]. It is totally biocompatible additionally investigated by many specialists within the frame of polymeric microparticle and hydrogel for conveyance of protein and peptide[76-81].Gel center liposomes are the progressed liposomal build bearing center of biocompatible polymer interior the lipid vesicle. This system is the combination of polymer and lipid based delivery system, in which core of polymer serves function of skeleton and provides mechanical support to vesicles and in this way gelling will be actuated after division of unentrapped polymer. It is stabilized liposome with all of the advantage of liposome imitating cell layer focusing on controlled discharge interaction with particular cells with elimination of single drawback of instability and with added advantage of controlled release for prolonged period of time. It contain three unmistakable situations for drugs to break up within the water lipid interface the hydrophobic center and the watery insides. Within the show work of it was arranged by turn around stage vanishing strategy and optimized by implies of different in vitro considers The most common polymer used is polyethylene glycol polymer (PEG). There's a reported increment of in vivo solidness of liposomes containing peg lipids is likely due to the arrangement of a steric obstruction which ruins the approach of various blood proteins[82]. It is in this manner of awesome significance to extend the information of the physical impacts of peg lipid on liposomal properties $\mathrm{pH}$ or temperature in the presence of specific ions or low molecular weight cross-linking agents. Thus, gel core liposomes can act as a novel controlled release system[8389]. The objective of this study was to prepare a modified liposomal carrier with a gelatinized core aiming for higher entrapment efficiencies of hydrophilic molecules and to develop a stabilized liposome by imparting a core of polymer in it and its comparison with conventional liposomes (liposomes prepared by $7: 3$ ratio of soya PC and cholesterol) for better controlled and sustained release properties of such molecules.

\section{DRUG PENETRATION PATHWAY}

Sedate can be entered by three pathways such as transcellular course, paracellular lipid course and transappendgeal course (Figure 2).

Transcellular Course:- Moeity passes through both keratinocytes and lipids (straight way to the dermis) [90]

Paracellular Course:-The foremost common entrance pathway of sedate atoms. In this pathway, medicate remains in lipid moeity and remain around keratin (simple for lipid solvent sedate instead of proteins)[91].

Transappendgeal Course:- It makes proceeds channel for sedate saturation but it ruined effectively due to nearness of hair follicles and sweat conduits.

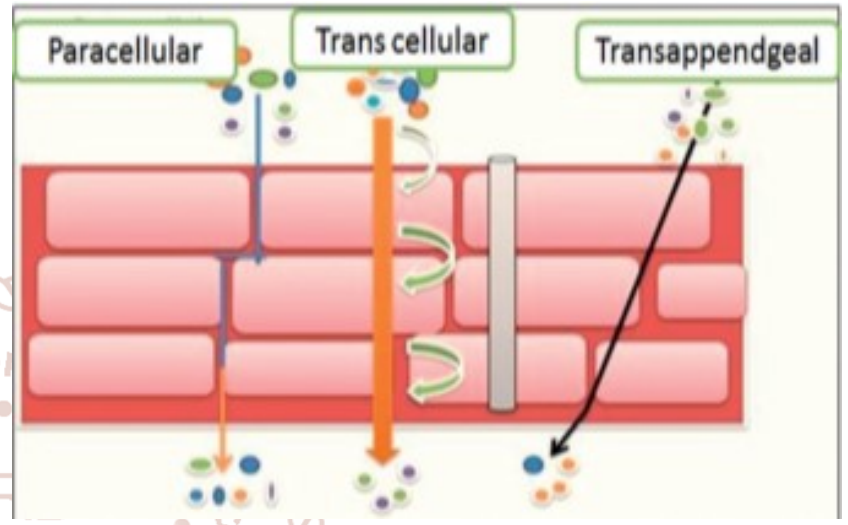

Figure :-2 Drug permeation pathway through skin.

\section{STRATEGIES APPLIED FOR PERMEATION ENHANCEMENT}

A very small number of drugs have the ability to effectively cross the skin barrier and reach target sites in therapeutic concentrations and Drawback of transdermal Conveyance is penetration of dynamic moeity through skin. So, various studies are done for enhancing its permeability percutaneously and therefore various strategies can be employed to help the drug cross the skin barrier effectively. They act by three mechanisms:

1. By altering physicochemical properties of stratum corneum.

2. By changing hydrating property of stratum corneum.

3. By altering structure of lipids and protein in intercellular channel via carrier mechanism

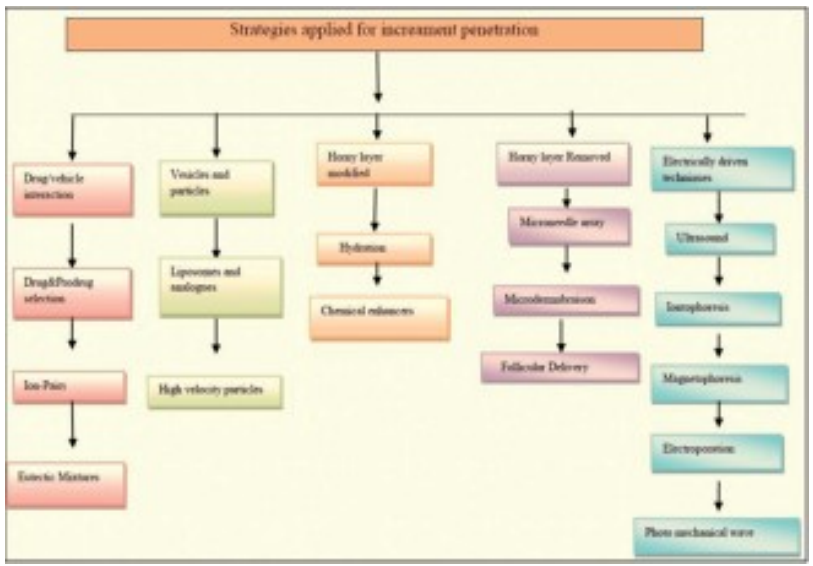

Figure:- 3. Advance strategies to overcome problems related to transdermal delivery. 
International Journal of Trend in Scientific Research and Development (IJTSRD) @ www.ijtsrd.com eISSN: 2456-6470

\begin{tabular}{|c|l|}
\hline Chemical class & \multicolumn{1}{|c|}{ Compounds } \\
\hline Water & Water \\
\hline Hydrocarbons & Alkanes, alkenes, squalene, mineral oil, halogens \\
\hline Alcohols & Glycerols, glycols, polyglycol, ethanol, caprylic alcohol \\
\hline Acids & Oleic acid, Undecanoic acid and other fatty acids \\
\hline Amines & Primary, secondary and tertiary, cyclic and acyclic amines \\
\hline Amides & $\begin{array}{l}\text { Pyrrolidone(N-methyl-2-pyrrolidone 2-pyrrolidon)azones } \\
\text { (Azone (1-dodecylazacycloheptan-2-one))urea }\end{array}$ \\
\hline Esters & Isopropyl myristate \\
\hline $\begin{array}{c}\text { Surfactants (anionic } \\
\text { Zationic,monolaurate non-ionic, } \\
\text { Zwitterionic) }\end{array}$ & $\begin{array}{l}\text { Sodium lauryl sulfate, cetyltrimethyl ammonium bromide, } \\
\text { sorbitan polysorbate 80,dodecyl dimethyl ammoniopropane } \\
\text { sulfate }\end{array}$ \\
\hline Terpenes, terpenoids and essential \\
oils & Menthol, limonene \\
\hline Sulfoxides & Dimethyl sulfoxide, dodecyl methyl sulfoxide \\
\hline Lipids & Phospholipids \\
\hline
\end{tabular}

Table 2. Classification of percutaneous chemical enhancers on the bases of their structure.

\subsection{Additional methods:-}

\section{A. Photomechanical wave}

It is additionally named as laser-generated stretch weight wave, which is produced by cut of the focused on substance polystyrene. It has no particular component of activity, but it changes the lacnuar framework within the epidermis as appeared in( Figure 3). This procedure is able in conveying of macromolecules (40000 Da)

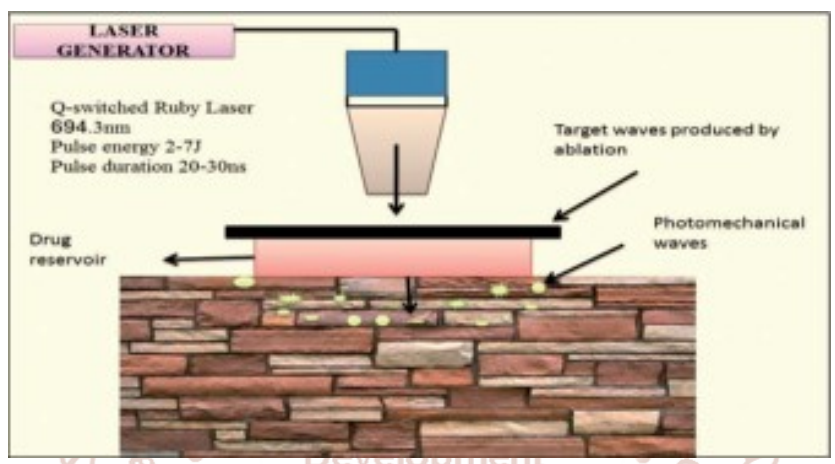

Figure:-3 Showing Photomechanical Wave

\section{B. High-velocity particles Powderject device}

It consist of propulsion of solid drug into skin by gas (helium) as medium with a speed of 600-900 m/s (Figure 4). This technique is painless and non-invasive. This system ruptures the epidermal layer which is reversible in nature.

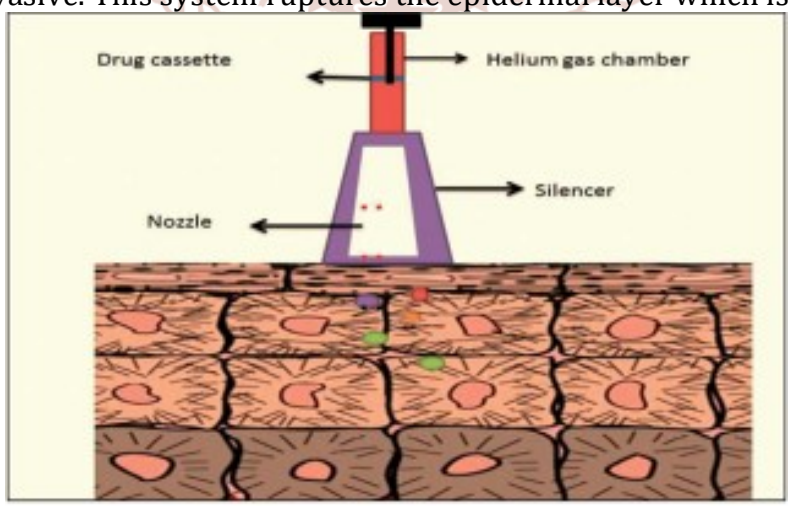

Figure:-4 Shows powderjet device

\section{Needle-free injections}

This method consist of non-invasive technique which is boon over conventional dosage form. Some of its injectors are as follows:

Intrajet: It uses nitrogen propelled gas. Patient breaks up the tip and presurized gas forces the liquid drug into generated small pores.

Implajet: It pushes a fine needle into the skin with opens channels and drug permeates immediatly.

Jet-syringe: This is capable of delivering $0.5 \mathrm{ml}$ dose into the skin. It is best for short therapies

Ilject: It is capable of delivering drug upto 0.1-1 $\mathrm{ml}$ drug and it is needle-free therapy.

Miniject: This velocity injector uses polycarbonate syringe which can deliver drug subcutaneously as well as intramusculary. Cross-ject: This needle-free device uses gas source to propelled drug into subcutaneous tissue with the help of polycarbonate nozzle[92]. 
International Journal of Trend in Scientific Research and Development (IJTSRD) @ www.ijtsrd.com eISSN: 2456-6470

\begin{tabular}{|c|c|c|c|c|}
\hline Technique & Trans ort & Sustained delivery & Pain & Cost \\
\hline Chemical enhancer & Good & Moderate & Limited & Good \\
\hline Iontophoresis & Limited & Good & Moderate & Good \\
\hline Electroporation & Moderate & Good & Moderate & Limited \\
\hline Ultrasound & Moderate & Good & Good & Limited \\
\hline Microneedles & Moderate & Good & Good & Limited \\
\hline High-velocity particles & Good & Limited & Limited & Limited \\
\hline
\end{tabular}

Table 3. Comparison between different transdermal drug delivery systems on the basis of various pharamceutical aspects.

\section{MECHANISMS OF DRUG PENETRATION IN SKIN FROM LIPOSOMES}

Liposomes with rigid bilayers tend to confine the drug locally in the skin. For deeper penetration, liposomes with flexible bilayers perform better. This flexibility is often induced by incorporation of surfactants often termed as 'edge activators' which reduce the elastic modulus of the phospholipid bilayer.

Liposomal drug delivery to the skin can be classified in five different mechanisms or pathways as shown in Figure 5[93].

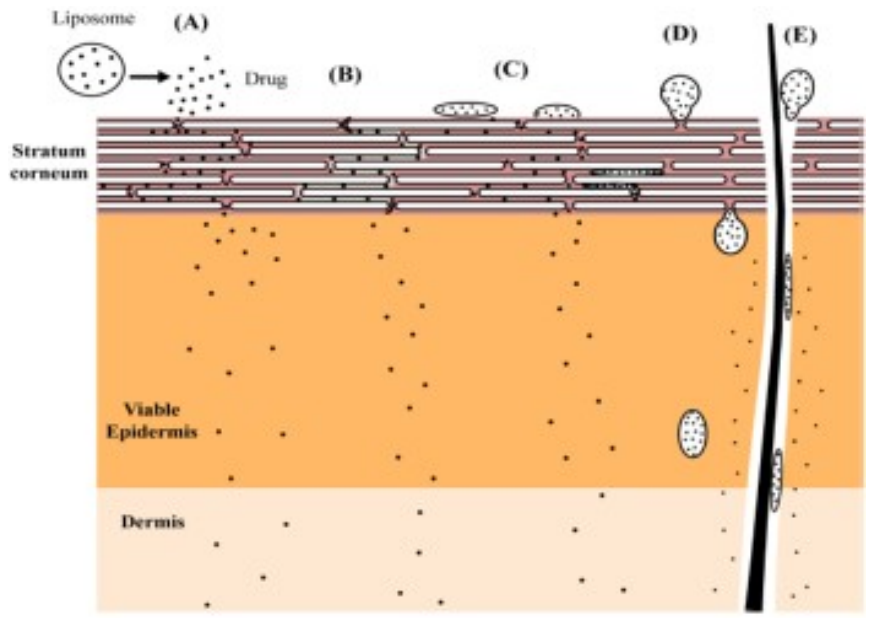

Figure 5: Schematic showing various mechanisms by which liposomes can facilitate drug delivery to skin.

According to this classification:- (1) liposomes can either act as drug carriers bringing different lipophilic and hydrophilic drugs in close proximity to the SC from where drug partitions into the SC independent of the liposomal components. (2)It recommends that components of the liposomes act as entrance enhancers which facilitate in the penetration of the drugs. (3) It suggests that liposomal bilayers can fuse or get adsorbed on the surface of the SC where they release their drug cargo. (4) The most controversial mechanism suggests that flexible liposomes such as Transfersomes can penetrate the SC intact and therefore taking the drug cargo along with them. (5) The transfollicular mechanism, where liposomes can enter the hair follicles which typically penetrate the dermis and release the drug in the hair follicles which can diffuse out in the dermis or viable epidermis from within the hair follicle. Which mechanism or combination of two or multiple mechanisms dominate in any given drug liposomal system combination would depend on the physicochemical properties of the drug and liposomal system.

\section{CURRENT STATUS OF LIPOSOMES IN TRANSDERMAL DRUG DELIVERY SYSTEMS}

This section will take a closer see at the liposomal formulations for drug delivery to skin. Liposomes were to begin with recommended by mezei and gulasekharam in 1980 as a medicate conveyance framework for depositing triamcinolone in skin[94]. Liposomes are phospholipid vesicles containing one or more bilayers containing an aqueous core. A point by point survey for diverse planning strategies characterization and properties of liposomes can be found somewhere else[95-97]. Liposomes in skin drug delivery applications have a rather controversial history. Ambiguity originates from the wide array of results that have been reported by various work groups. Liposomes have been even shown to accumulate in the hair follicles [98-100]. Liposomes have also shown the ability to improve transdermal delivery of small molecules as well as peptides and proteins[101,93]. Reasons for the disparity between different results of different studies likely originate from; differences in composition of liposomes, different physicochemical Properties of the liposomal vesicles added substances to the liposomes such as ethanol edge activators entrance enhancers more over adjust the bilayer characteristics and drug transfer from the liposomal bilayer, use of different animal models etc. Intuitive of liposome with the skin and sedate exchange from liposome to skin are impacted by the thermodynamic state of the liposomal bilayers and so influenced by the nature of phospholipids used in the preparation of the liposomes. Depending on the composition liposomal bilayers can exist in gel state characterized by inflexible and unwavering bilayers or fluid crystalline state where bilayers or liquid crystalline state where bilayers are flexible and accommodating. Liposomal details in gel state are more often than not related with medicate amassing within the upper layers of the skin and indeed diminished transdermal medicate infiltration[102-103,94]. For skin application, liposomal definitions can be isolated in two wide categories as customary liposomes and novel liposomes(deformable or ultra deformable or elastic liposomes) [104]. Ordinary liposomes are basically composed of pure or mixtures of phospholipid(s) and may or may not contain cholesterol. 
In spite of the fact that a couple of considers have recommended plausibility of transdermal sedate conveyance utilizing customary liposomes a tremendous number of thinks about suggest conventional liposomes are more suitable for topical or local delivery of drug in the skin[105-106]. Second category represents an array of different liposomal systems which apart from phospholipids contain other additives which essentially imparts the liposome bilayer deformability or elasticity which has been correlated to increased drug permeability in skin[107-111].

\begin{tabular}{|c|l|}
\hline Formulations Work group & \multicolumn{1}{c|}{ Bilayer forming lipid and other additives } \\
\hline $\begin{array}{c}\text { Transfersomes } ® \\
\text { Cevc } \text { et al. }\end{array}$ & $\begin{array}{l}\text { Soya phosphatidylcholine (S100, Lipoid GmbH). See table 3 for composition. } \\
\text { Edge activators, sodium cholate, polysorbate 80, sorbitan monooleate 80 etc. }\end{array}$ \\
\hline $\begin{array}{c}\text { Ethosomes } \\
\text { Touitou } \text { et al. }\end{array}$ & $\begin{array}{l}\text { Soya phosphatidylcholine (S100, Lipoid GmbH) 10-50\% ethanol by weight which } \\
\text { fluidizes the phospholipid bilayers }\end{array}$ \\
\hline $\begin{array}{c}\text { Invasomes } \\
\text { Fahr et al }\end{array}$ & $\begin{array}{l}\text { Soya phospholipid (NAT 8539, Lipoid GmbH) See table 4 for composition. } \\
\text { Lyso phosphatidylcholine as an edge activator, 1\% terpenes and 10\% ethanol by weight } \\
\text { as penetration enhancers }\end{array}$ \\
\hline Niosomes & $\begin{array}{l}\text { Non-ionic surfactants such as dicetylphosphate, hexadecyl diglycerol ether, polysorbates, } \\
\text { sorbitan monooleates etc and cholesterol }\end{array}$ \\
\hline
\end{tabular}

Table 3: A brief description of the liposomal systems for skin drug delivery

\section{FUTURE ASPECTS}

\section{Hyaluronic acid}

More as of late gel center filled liposomes have been utilized effectively for transdermal medicate conveyance of little and macromolecules such as curcumin and hyaluronic acid[31-32]. These novel liposomes are composed of phospholipid vesicles entangling gel fabric in their center. Therefore, they can combine the advantages of liposomes and gel formulations in one drug delivery system[33].There were no measurably critical contrasts $p>05$ among normal estimate breadths for ethosomes pg liposomes transferosomes and hyaluosomes. Further, the effect of PG and ethanol concentrations had no statistically significant $(P>0.05)$ effects on the average diameter. Comparable comes about were detailed somewhere else with cinchocaine PEG liposomes, ethosomes and transferosomes[112].

\begin{tabular}{|c|c|c|c|c|c|c|c|c|}
\hline $\begin{array}{l}\text { Liposomal } \\
\text { Systems }\end{array}$ & $\begin{array}{c}\text { Z average } \\
\text { diameter } \\
(\mathrm{nm})\end{array}$ & PDI & $\begin{array}{c}\text { Zeta } \\
\text { potential } \\
(\mathrm{mV})\end{array}$ & $\begin{array}{c}\text { EE\% } \\
(w / w)\end{array}$ & $\begin{array}{c}\text { Release } \\
\text { rate } \\
02 \mathrm{~h} \\
(\% \mathrm{w} / \mathrm{w}) \\
\end{array}$ & $\begin{array}{c}\text { Release } \\
\text { rate } \\
\text { constant } \\
(\mathrm{K} ; \mathrm{h}-1) \\
\end{array}$ & $\begin{array}{c}\text { Release } \\
\text { exponent } \\
\text { (n) }\end{array}$ & $\begin{array}{l}\text { Correlation } \\
\text { coefficient } \\
\text { (r) }\end{array}$ \\
\hline $\begin{array}{c}\text { Conventional } \\
\text { liposomes }\end{array}$ & $700 \pm 10$ & $0.5 \pm 0.1$ & $-28 \pm 3$ & $55 \pm 4$ & d $47 \pm 3.5$ & $1.6 \pm 0.2$ & 0.43 & 0.997 \\
\hline $\begin{array}{c}\text { PG-liposomes } \\
(10 \% \mathrm{v} / \mathrm{v}) \\
\end{array}$ & $160 \pm 6.0$ & $0.2 \pm 0.03$ & $-33 \pm 3$ & $86 \pm 1.5$ & $29 \pm 1.5$ & $1.38 \pm 0.1$ & 0.35 & 0.994 \\
\hline $\begin{array}{c}\text { PG-liposomes } \\
(20 \% \mathrm{v} / \mathrm{v})\end{array}$ & $175 \pm 4.0$ & $0.22 \pm 0.04$ & $-35 \pm 2$ & $84 \pm 2$ & $31 \pm 3.0$ & $1.40 \pm 0.12$ & 0.44 & 0.992 \\
\hline $\begin{array}{l}\text { Ethosomes } \\
(20 \% \mathrm{v} / \mathrm{v}) \\
\end{array}$ & $166 \pm 5.0$ & $0.17 \pm 0.02$ & $-34 \pm 3$ & $82 \pm 2.4$ & $28 \pm 2.0$ & $1.20 \pm 0.8$ & 0.45 & 0.995 \\
\hline $\begin{array}{c}\text { Ethosomes } \\
(30 \% \mathrm{v} / \mathrm{v})\end{array}$ & $177 \pm 6.0$ & $0.23 \pm 0.04$ & $-35 \pm 2$ & $80 \pm 3.6$ & $38 \pm 1.5$ & $1.50 \pm 0.13$ & 0.43 & 0.992 \\
\hline $\begin{array}{c}\text { Transferosomes } \\
(5 \% \mathrm{v} / \mathrm{v})\end{array}$ & $180 \pm 3.5$ & $0.22 \pm 0.03$ & $-34 \pm 3$ & $81 \pm 3.2$ & $26 \pm 1.5$ & $1.34 \pm 0.13$ & 0.42 & 0.990 \\
\hline $\begin{array}{c}\text { Transferosomes } \\
(10 \%)\end{array}$ & $188 \pm 5.5$ & $0.22 \pm 0.02$ & $-35 \pm 2.5$ & $79 \pm 3.5$ & $29.5 \pm 3$ & $1.42 \pm 0.12$ & 0.45 & 0.992 \\
\hline Hyaluosomes & $180 \pm 4.5$ & $0.15 \pm 0.03$ & $0.15 \pm 0.03$ & $82 \pm 2$ & $17 \pm 1.5$ & $1.0 \pm 0.4$ & 0.46 & 0.995 \\
\hline
\end{tabular}

Table 4 Size, PDI, zeta potential, entrapment efficiency (EE \%), release kinetics for the prepared liposomal systems.

Results are expressed as mean \pm standard deviation.

The zeta potential recorded for the prepared liposomal systems was negative and ranged from -28 to $-40 \mathrm{mV}$ (Table 1). Zeta potential is the magnitude of the electrostatic charge and it gives an idea about the stability of the colloidal system. The greater the zeta potential, the more stable the colloidal system and the lower tendency of the particles to aggregate and lower PDI. The zeta potential $(-28 \mathrm{mV})$ recorded for the conventional liposomes was the lowest. This may incompletely clarify their generally tall PDI, compared with other non-conventional liposomes. It is worth specifying that hyaluosomes recorded the biggest zeta potential and this might be attributed to consolidation of the anionic hydrophilic polymer hyaluronic acid that exists overwhelmingly in ionized shapes at pH 7.4[113]. EE\% evaluated for the arranged diverse liposomal frameworks extended from $55 \%$ to $84 \%$ while the routine liposomes appeared altogether $\mathrm{p}<05$ lower EE\%; no statistically significant $(\mathrm{P}>0.05)$ Contrasts were recorded among EE\% for the distinctive non ordinary liposomal frameworks pg liposomes, ethosomes, transferosomes and hyaluosomes. Nearness of the film added substances eminently pg ethanol

tween 80 and hyaluronic acid appears to create more steady vesicles with less inclinations to total and become less leaky to the entrapped drug molecules, compared with the conventional liposomes.

\section{CONCLUSIONS}

Skin saturation upgrade innovation may be a quickly developing field which would expressively increment the 
number of drugs which is appropriate for transdermal medicate conveyance. Approaches the investigation for the perfect skin entrance enhancer has been the accentuation of critical inquire about exertion over a number of times. We hypothesize that the developed new liposomal carrier system possessing a gelatinized core can contribute in the successful delivery of hydrophilic drugs. The characterization of the prepared liposomes and the results of the hydrophilic molecule-release experiments showed favorable rheological properties, high entrapment efficiencies and sustained drug release and better stability. Ultra-flexible Liposomes improve the infiltration independent of the drug's measure compared to liquid liposomes. This data proposes that liposomes can either improve or decrease skin entrance depending on the atomic weight of the sedate and the liposome composition. All deformable liposomes displayed tall hEGF substance with a somewhat higher stack for anionic deformable liposomes. hEGF containing anionic deformable liposomes shown the foremost maintained hEGF in vitro discharge and guaranteed a station on the ex vivo human skin as compared to impartial and cationic deformable liposomes. . The novel gel center phospholipid vesicles hyaluosomes as a promising transdermal definition framework since they illustrated ideal rheological characteristics such as thermal gelation and shear-thinning behaviours for better retention at the site of application on the skin and spreading ability respectively.

\section{REFERENCES}

[1] Kenneth AW, Michael SR (2002) The Structure and Function of Skin. In: Dermatological and Transdermal Formulations (CRC Press.

[2] PRAUSNITZ, M. R. \& LANGER, R. 2008. Transdermal drug delivery. Nature Biotechnology, 26, 1261-1268.

[3] ALEXANDER, A., DWIVEDI, S., GIRI, T. K., SARAF, S., SARAF, S. \& TRIPATHI, D. K. 2012. Approaches for breaking the barriers of drug permeation through transdermal drug delivery. J. Control. Rel., 164164 (2012) 26-40.

[4] Singh 0, Garg T, Rath G, Goyal AK. (2014c). Microbicides for the treatment of sexually transmitted hiv infections. J Pharm 1-18.

[5] Guy RH: Current status and future prospects of transdermal drug delivery. Pharm Res 1996, 13:17651769.

[6] Park D, Park H, Seo J, et al. Sonophoresis in transdermal drug deliverys. Ultrasonics. 2014;54:56-65.

[7] Trommer H, Neubert RH. Overcoming the stratum corneum: the modulation of skin penetration. A review. Skin Pharmacol Physiol. 2006;19:106-121.

[8] Touitou E, Godin B. Ethosomes for skin delivery. J Drug Del Sci Tech. 2007;17:303-308.

[9] Ibrahim MA, Yusrida D, Nurzalina Abdul Karim K, et al. Ethosomal nanocarriers: the impact of constituents and formulation techniques on ethosomal properties, in vivo studies, and clinical trials. Int J Nanomedicine. 2016;11: 2279-2304.

[10] Weaver JC, Chizmadzhev YA: Theory of electroporation: a review. Bioelectrochemistry and Bioenergetics 1996, 41:135-160.

[11] McElnay JC, Benson HAE, Hadgraft J, Murphy M: The use of ultrasound in skin penetration enhancement. In Pharmaceutical Skin Penetration Enhancement Edited by: Walters K, Hadgraft J. New York:Marcel Dekker; 1993:293-309.

[12] Mitragori S, Blankschtein D, Langer R: Ultrasound mediated transdermal protein delivery. Science 1995, 269:850-853.

[13] Benson HAE, McElnay JC, Harland R, Hadgraft J: Influence of ultrasound on the percutaneous absorption of nicotinate esters. Pharm Res 1991, 8:204209.

[14] Higuchi T: Physical chemical analysis of percutaneous absorption process from creams and ointments. J Soc Cosmet Chem 1960, 11:85-97.

[15] Raghavan SL, Trividic A, Davis AF, Hadgraft J: Effects of cellulose polymers on supersaturation and in vitro membrane transport of hydrocortisone acetate. Int J Pharm 2000, 193:231-237.

[16] Choi AHC, Basu M, Era MN, McNeal MM, Ward RL: Particle bombarded- mediated DNA vaccination with rotavirus VP4 or VP7 induces high levels of serum rotavirus IgG but fails to protect mice against challenge. Virology 1998, 250:230-240.

[17] Henry S, McAllister DV, Allen MG, Prausnitz MR: Microfabricated microneedles: A novel appoach to transdermal drug delivery. J Pharm Sci 1998, 87:922925.

[18] DeNoble LJ, Knutson K, Kurihara-Bergstrom T: Enhanced skin permeability by ethanol: Mechanistic studies of human stratum corneum measured by DSC and FTIR. Pharm Res 1987, 4:59s.

[19] Embery G, Dugard PH: The isolation of dimethyl sulfoxide soluble components from human epidermal preparations: A possible mechanism of action of dimethyl sulfoxide in affecting percutaneous migration phenomena. J Invest Dermatol 1971, 57:308-311.

[20] Abraham W: Surfactant effects on skin barrier. In Surfactants in Cosmetics Edited by: Rieger MM, Rhein LD. New York: Marcel Dekker;1997:473-487.

[21] Bennet SL, Barry BW: Effect of penetration enhancers on the permeation of mannitol, hydrocortisone and progesterone through human skin. J Pharm Pharmacol 1987, 39:536-546.

[22] Hadgraft J: Passive enhancement strategies in topical and transdermal drug delivery. Int J Pharm 1999, 184:1-6.

[23] Hadgraft J, Williams DG, Allan G: Azone: Mechanisms of action and clinical effect. In Pharmaceutical Skin Penetration Enhancement Edited by: Walters $K$, Hadgraft J. New York: Marcel Dekker;1993:175-198.

[24] Hadgraft J, Peck J, Williams DG, Pugh WJ, Allan G: Mechanisms of action of skin penetration enhancers/retarders: Azone and analogues. Int J Pharm 1996, 141:17-25.

[25] Allen TM, Hansen CB, Stuart DD. Targeted sterically stabilized liposomal drug delivery. In: Lassic DD, Papahadjopoulos D, editors. Medical applications of liposomes. Amsterdam: Elsevier; 1978. pp. 297.

[26] Manconia M, Pendas J, Ledon N, et al. Phycocyanin liposomes for topical anti-inflammatory activity: invitro in-vivo studies. J Pharm Pharmacol. 2009;61:423430. 
International Journal of Trend in Scientific Research and Development (IJTSRD) @ www.ijtsrd.com eISSN: 2456-6470

[27] Touitou E. Drug delivery across the skin. Expert Opin Biol Ther. 2002;2:723-733.

[28] Chourasia MK, Kang L, Chan SY. Nanosized ethosomes bearing ketoprofen for improved transdermal delivery. Results Pharma Sci. 2011;1:60-67.

[29] ELSAYED, M. M., ABDALLAH, O. Y., NAGGAR, V. \& KHALAFALLAH, N. M. 2007a. Lipid vesicles for skin delivery of drugs: Reviewing three decades of research. Int. J.Pharm., 332, 1-16.

[30] ZHANG, Y. T., SHEN, L., WU, Z. H., ZHAO, J. H. \& FENG, N. P. 2014. Comparison of ethosomes and liposomes for skin delivery of psoralen for psoriasis therapy.Int. J. Pharm., 471, 449-452.

[31] EL-REFAIE, W. M., ELNAGGAR, Y., EL-MASSIK, M. \& ABDALLAH, O. Y. 2015b. Novel self-assembled, gel-core hyaluosomes for non-invasive management of osteoarthritis: in-vitro optimization, ex-vivo and invivo permeation. Pharm.Res., 32, 2901-2911.

[32] EL-REFAIE, W. M., ELNAGGAR, Y., EL-MASSIK, M. \& ABDALLA, 0. 2015a. Novel curcumin-loaded gel-core hyaluosomes with promising burn-wound healing potential: Development, in-vitro appraisal and in-vivo studies. Int. J. Pharm.,486 88-98.

[33] ELNAGGAR, Y. S., EL-REFAIE, W. M., EL-MASSIK, M. A.\& ABDALLAH, O.Y. 2014.Lecithin-based nanostructured gels for skin delivery: an update on state of art and recent applications. . J. Control. Release., 180, 10-24.

[34] Schaefer H, Redelmeier T (1996) Structure and dynamics of the skin barrier. In: Skin Barrier: Principles of Percutaneous Absorption (Basel: Karger), 1-42.

[35] Fukushima K, Ise A, Morita H, et al. (2011). Twolayered dissolving microneedles for percutaneous delivery of peptide/protein drugs in rats. Pharm Res 28:7-21.

[36] Cevc G, Vierl U (2010) Nanotechnology and the transdermal route: A state of the art review and critical appraisal. Journal of controlled release : official journal of the Controlled Release Society 141:277-99.

[37] Feldmann RJ, Maibach HI (1965) PENETRATION OF 14C HYDROCORTISONE THROUGH NORMAL SKIN: THE EFFECT OF STRIPPING AND OCCLUSION. Arch Dermatol 91:661-6.

[38] Kranz G, Schaefer H, Zesch A (1977) Hydrocortisone (cortisol) concentration and penetration gradient. Acta Derm Venereol 57:269-73.

[39] Malkinson FD. (1963) Radioactive agents and radioisotopes in dermatology: Investigative applications. In: PILLSBURY DM, LIVINGOOD CS (eds) Proceedings of the Conference Radioactive agents and radioisotopes in dermatology: Investigative applications; 1963 1962; Washington DC. Excerpta Medica Foundation: Amsterdam.

[40] Schaefer H, Zesch A, Stättgen G (1982) Skin Permeability. In: Skin Permeability (Springer Berlin Heidelberg, 541-845.

[41] Scheuplein RJ, Blank IH (1971) Permeability of the skin. Physiol Rev 51:702-47.

[42] Washitake M, Yajima T, Anmo T, et al. (1973) Studies on percutaneous absorption of drugs. 3. Percutaneous absorption of drugs through damaged skin. Chemical \& pharmaceutical bulletin 21:2444-51.
[43] Winkelmann RK, Breathnach AS (1973) THE MERKEL CELL. J Investig Dermatol 60:2-15.

[44] Nolano M, Simone DA, Wendelschafer-Crabb G, et al. (1999) Topical capsaicin in humans: parallel loss of epidermal nerve fibers and pain sensation. Pain 81:135-45.

[45] Sun R, Celli A, Crumrine D, et al. (2014). Functional epidermal permeability barrier in human epidermal equivalents. Tissue Eng Part C Methods. [Epub ahead of print].

[46] Singh H, Sharma R, Joshi M, et al. (2014b). Transmucosal delivery of docetaxel by mucoadhesive polymeric nanofibers. Artif Cells Nanomed Biotechnol. [Epub ahead of print]. doi: 10.3109/ 21691401.2014.885442.

[47] Ng KW, Lau WM (2015) Skin deep: The basics of human skin structure and drug penetration. In: Percutaneous Penetration Enhancers: Chemical Methods in Penetration Enhancement (Dragicevic N, Maibach HI, eds) Vol. I: Springer-Verlag, 4-11.

[48] Higuchi WI (1962) Analysis of data on the medicament release from ointments. J Pharm Sci 51:802-4.

[49] Herrmann F, Mandol L (1955) Studies of Ph of Sweat Produced by Different Forms of Stimulation1. The Journal of investigative dermatology 24:225-46.

[50] Krause K, Foitzik K (2006) Biology of the hair follicle: the basics. Semin Cutan Med sc

[51] Dhote V, Bhatnagar P, Mishra PK, et al. (2012). Iontophoresis: a potential emergence of a transdermal drug delivery system. Sci Pharm 80:1-28.

[52] Park CW, Son DD, Kim JY, et al. (2012). Investigation of formulation factors affecting in vitro and in vivo characteristics of a galantamine transdermal system. Int J Pharm 436:32-40.

[53] Rehman K, Zulfakar MH. (2014). Recent advances in gel technologies for topical and transdermal drug delivery. Drug Dev Ind Pharm 40:433-40.

[54] Schoellhammer CM, Blankschtein D, Langer R. (2014). Skin permeabilization for transdermal drug delivery: recent advances and future prospects. Expert Opin Drug Deliv 11:393-407.

[55] Jones DS, Moss GP. (2010). Themed issue: recent advances in transdermal drug delivery. J Pharm Pharmacol 62:669-70.

[56] Subedi RK, Oh SY, Chun MK, Choi HK. (2010). Recent advances in transdermal drug delivery. Arch Pharm Res 33:339-51.

[57] Barenholz Y. Doxil(R)--the first FDA-approved nanodrug: lessons learned. J Control Release. 2012; 160: 117-34.

[58] Luk BT, Fang RH, Zhang L. Lipid- and polymer-based nanostructures for cancer theranostics. Theranostics. 2012; 2: 1117-26.

[59] Allen, T.M., Hansen, C.B., Lopes-de-Menezes, D.E., 1995.Pharmacokinetics of long-circulating liposomes. Adv.Drug Del. Rev. 16, 267-284.

[60] Chonn, A., Cullis, P.R., 1995. Recent advaces in liposomal drug-delivery systems. Curr. Opin. Biotechnol. 6, 698-708. 
International Journal of Trend in Scientific Research and Development (IJTSRD) @ www.ijtsrd.com eISSN: 2456-6470

[61] Woodle, M., 1995. Sterically stabilized liposome therapeutics. Adv. Drug Del. Rev. 16, 249-265.

[62] Gabizon, A., Chemla, M., Tzemach, D., Horowitz, A.T., Goren, D., 1996. Liposome longevity and stability in circulation: effects on the in vivo delivery to tumors and therapeutic efficacy of encapsulated anthracyclines. J.Drug Targ. 3, 391-398.

[63] Planas, M. E., Gonzalez, P., Rodriguez, L., Sanchez, S. \& Cevc, G. Noninvasive percutaneous induction of topical analgesia by a new type of drug carrier, and prolongation of local pain insensitivity by anesthetic liposomes. Anesth. Analg. 75, 615-621 (1992).

[64] Hofer, C., Göbel, R., Deering, P., Lehmer, A. \& Breul, J. Formulation of interleukin-2 and interferon-alpha containing ultradeformable carriers for potential transdermal application. Anticancer Res. 19, 15051507 (1999).

[65] Cevc, G. \& Blume, G. Biological activity and characteristics of triamcinolone-acetonide formulated with the self-regulating drug carriers, Transfersomes ${ }^{\circledR}$. Biochim. Biophys. Acta - Biomembr. 1614, 156-164 (2003).

[66] Ntimenou, V., Fahr, A. \& Antimisiaris, S. G. Elastic vesicles for transdermal drug delivery of hydrophilic drugs: a comparison of important physicochemical characteristics of different vesicle types. J. Biomed. Nanotechnol. 8, 613-623 (2012).

[67] Ashraf, O., Nasr, M., Nebsen, M., Said, A. M. A. \& Sammour, 0. In vitro stabilization and in vivo improvement of ocular pharmacokinetics of the multitherapeutic agent baicalin: Delineating the most suitable vesicular systems. Int. J. Pharm. 539, 83-94 (2018).

[68] Rai, K., Gupta, Y., Jain, A. \& Jain, S. K. PDAJ. Pharm. Sci. Technol. 62, 362-379 (2008).

[69] Cosco, D. et al. Ultradeformable liposomes as multidrug carrier of resveratrol and 5-fluorouracil for their topical delivery. Int. J. Pharm. 489, 1-10 (2015).

[70] Benson, H. A. E. Transfersomes for transdermal drug delivery. Expert Opin. Drug Deliv. 3, 727-737 (2006).

[71] Carrer, D. C. et al. Structural features of ultradeformable archaeosomes for topical delivery of ovalbumin. Colloids Surf. B. Biointerfaces 121, 281-289 (2014).

[72] Carrer, D. C., Vermehren, C. \& Bagatolli, L. A. Pig skin structure and transdermal delivery of liposomes: a two photon microscopy study. J. Control. Release 132, 12-20 (2008).

[73] Montanari, J. et al. Sunlight triggered photodynamic ultradeformable liposomes against Leishmania braziliensis are also leishmanicidal in the dark. J. Control. Release 147, 368-376 (2010).

[74] Cevc, G. Lipid vesicles and other colloids as drug carriers on the skin. Adv. Drug Deliv. Rev. 56, 675-711 (2004).

[75] Cevc, G., Gebauer, D., Stieber, J., Schatzlein, A. \& Blume, G. Ultraflexible vesicles, Transfersomes, have an extremely low pore penetration resistance and transport therapeutic amounts of insulin across the intact mammalian skin. Biochim. Biophys. Acta 1368,201-215 (1998).
[76] A.B. Schnurch, C. Egger, M. Elhassan Imam, A.H. Krauland, Preparation and in vitro characterization of poly (acrylic acid)-cysteine microparticles, Journal of Controlled Release 93 (10) (2003) 29-38.

[77] D.C. Bibby, N.M. Davies, I.G. Tucker, Poly(acrylic acid) microspheres containing $\beta$-cyclodextrin: loading and in vitro release of two dyes, International Journal of Pharmaceutics 187 (1999) 243-250.

[78] D.S. MacLean, J.S. Robertson, M. Jay, D.J. Stalker, Noninvasive measurement of protein release from subcutaneous depo formulations in vivo using X-ray fluorescence,Journal of Controlled Release 34 (2) (1995) 167-173.

[79] M. Topuzogullar, N.S. Çimen, Z. Mustafaeva, M. Mustafaev, Molecular-weight distribution and structural transformation in water-soluble complexes of poly (acrylic acid) and bovine serum albumin, European Polymer Journal 43 (7) (2007) 2935-2946.

[80] M. Mustafae, F. Yiicel, B. Cirakoglu, E. Bermek, Immune response to progesterone involved in $\mathrm{Cu} 2+$-mediated polyanion-protein complex-antigen specificity and affinity of hybridoma clones, Immunology Letters 52 (1996) 63-68.

[81] M. Chuna, H. Sah, H.K. Choi, Preparation of mucoadhesive microspheres containing antimicrobial agents for eradication of $\mathrm{H}$. pylori, International Journal of Pharmaceutics 297 (2005) 172-179.

[82] Ceh, B., Winterhalter, M., Frederik, P.M., Vallner, J.J., Lasic, D.D., 1997. Stealth liposomes: from theory to product. Adv. Drug Del. Rev. 24, 165-177.

[83] Torchilin VP, Klibanou AL, Iuanou NN. 1987. Polymerization of liposome-encapsulated hydrophilic monomers. Macromol Chem Rapid Commun 8:457460.

[84] Fujiwara M, Baldeschwieler JD, Grubbs RH. 1996. Receptormediated endocytosis of poly(acrylic acid)conjugated liposomes by macrophages. Biochim et Biophys Acta 1278:59-67.

[85] Fujiwara M, Grubbs RH, Baldeschwieler JD. 1997. Characterization of $\mathrm{pH}$-dependent poly(acrylic acid) complexation with phospholipid cesicles. J Coll Inter Sci 185:210-216.

[86] Jin T, Pennefather P, Lee PI. 1996. Lipobeads: A hydrogel anchored lipid vesicle system. FEBS Lett 397:70-74.

[87] Tardi C, Brandla M, Schuberta R. 1998. Erosion and controlled release properties of semisolid vesicular phospholipid dispersions. J Control Rel 55:261-270.

[88] Viallat A, Dalous J, Abkarian M. 2004. Giant lipid vesicles filled with a gel: shape instability induced by osmotic shrinkage. Biophys J 86:2179-2187.

[89] Dai C, Wang B, Zhao H, Li B. 2005. Factors affecting protein release from microcapsule prepared by liposome in alginate. Coll Surf B Biointer 42:253-258.

[90] Ghaffarian R, Muro S. (2013). Models and methods to evaluate transport of drug delivery systems across cellular barriers. J Vis Exp (80):e50638.

[91] Parnami N, Garg T, Rath G, Goyal AK. (2013). Development and characterization of nanocarriers for topical treatment of psoriasis by using combination 
therapy. Artif Cells Nanomed Biotechnol. [Epub ahead of print]. doi: 10.3109/21691401.2013.837474.

[92] Garg T. (2012). An evolutionary approaches in development of needle free injection technologies. Int J Pharm Pharm Sci 4:590-6.

[93] El Maghraby GM, Barry BW, Williams AC (2008b) Liposomes and skin: From drug delivery to model membranes. European Journal of Pharmaceutical Sciences 34:203-22.

[94] Mezei M, Gulasekharam V (1980) Liposomes--a selective drug delivery system for the topical route of administration. Lotion dosage form. Life Sci 26:1473-7.

[95] Barenholz Y, Lasic DD (1996) Handbook of Nonmedical Applications of Liposomes. Taylor \& Francis.

[96] Gregoriadis G (2006) Liposome Technology: Liposome Preparation and Related Techniques. CRC Press.

[97] Torchilin V, Weissig V (2003) Liposomes: A Practical Approach. OUP Oxford.

[98] Patzelt, A., Lademann,J., 2013. Drug delivery to hair follicles. Expert Opin. Drug Deliv. 10, 787-797.

[99] Verma, D.D., Fahr, A., 2004. Synergistic penetration enhancement effect of ethanol and phospholipids on the topical delivery of cyclosporin A. J. Control. Release 97, 55-66.

[100] Vogt A, Mandt N, Lademann J, et al. (2005) Follicular targeting--a promising tool in selective dermatotherapy. The journal of investigative dermatology Symposium pmezroceedings / the Society for Investigative Dermatology, Inc [and] European Society for Dermatological Research 10:252-5.

[101] Benson HA (2009) Elastic liposomes for topical and transdermal drug delivery. Curr Drug Deliv 6:217-26.

[102] Hofland HE, van der Geest R, Bodde HE, et al. (1994) Estradiol permeation from nonionic surfactant vesicles through human stratum corneum in vitro. Pharm Res 11:659-64.

[103] Knepp VM, Hadgraft J, Guy RH (1987) Transdermal drug delivery: problems and possibilities. Critical reviews in therapeutic drug carrier systems 4:13-37.

[104] Dragicevic-Curic N, Fahr A (2012) Liposomes in topical photodynamic therapy. Expert opinion on drug delivery 9:1015-32.

[105] Deo MR, Sant VP, Parekh SR, et al. (1997) Proliposomebased transdermal delivery of levonorgestrel. Journal of biomaterials applications 12:77-88.

[106] Yu H-Y, Liao H-M (1996) Triamcinolone permeation from different liposome formulations through rat skin in vitro. International Journal of Pharmaceutics 127:1-7.

[107] Celia C, Cilurzo F, Trapasso E, et al. (2012) Ethosomes $(\mathrm{R})$ and transfersomes( $\mathrm{R})$ containing linoleic acid: physicochemical and technological features of topical drug delivery carriers for the potential treatment of melasma disorders. Biomedical microdevices 14:119-30.

[108] Cevc G, Blume G (2003) Biological activity and characteristics of triamcinolone-elacetonide formulated with the self-regulating drug carriers, Transfersomes. Biochimica et biophysica acta 1614:156-64.

[109] Cevc G, Mazgareanu S, Rother M, et al. (2008) Occlusion effect on transcutaneous NSAID delivery from conventional and carrier-based formulations. Int J Pharm 359:190-7.

[110] Touitou E, Dayan N, Bergelson L, et al. (2000) Ethosomes - novel vesicular carriers for enhanced delivery: characterization and skin penetration properties. Journal of controlled release : official journal of the Controlled Release Society 65:403-18.

[111] Wo Y, Zhang Z, Zhang Y, et al. (2011) Preparation of ethosomes and deformable liposomes encapsulated with 5-fluorouracil and their investigation of permeability and retention in hypertrophic scar. Journal of nanoscience and nanotechnology 11:7840-7.

[112] ELSAYED, M. M., ABDALLAH, O. Y., NAGGAR, V. F. \& KHALAFALLAH, N. M. 2007b. PGliposomes:novel lipid vesicles for skin delivery of drugs. J. Pharm.Pharmacol, 59, 1447-1450.

[113] NECAS, J., BARTOSIKOVA, L., BRAUNER, P. \& KOLAR, J. 2008 Hyaluronic acid (hyaluronan): a review. Veterinarni Medicina, 53, 397-411.

[114] Fang JY, Hong CT, Chiu WT, Wang YY. (2001). Effect of liposomesand niosomes on skin permeation of enoxacin. Int J Pharm 219:61-72.

[115] Li N, Peng LH, Chen X, et al. (2014). Antigen-loaded nanocarriersenhance the migration of stimulated Langerhans cells to draininglymph nodes and induce effective transcutaneous immunization.Nanomedicine 10:215-23.

[116] Jain S, Tiwary AK, Sapra B, Jain NK. (2007). Formulation andevaluation of ethosomes for transdermal delivery of lamivudine.AAPS PharmSciTech 8:E111.

[117] Manosroi A, Khanrin P, Lohcharoenkal W, et al. (2010). Transdermal absorption enhancement through rat skin of gallidermin loaded in niosomes. Int J Pharm 392:304-10.

[118] Romero EL, Morilla MJ. (2013). Highly deformable and highly fluid vesicles as potential drug delivery systems: theoretical and practical considerations. Int J Nanomed 8:3171-86.

[119] Dubey V, Mishra D, Jain NK. (2007). Melatonin loaded ethanolic liposomes: physicochemical characterization and enhanced transdermal delivery. Eur J Pharm Biopharm 67:398-405.

[120] Kim ST, Lee KM, Park HJ, et al. (2009). Topical delivery of interleukin- antisense oligonucleotides with cationic elastic liposome for thetreatment of atopic dermatitis. J Gene Med 11:26-37.

[121] Chen M, Gupta V, Anselmo AC, et al. (2014). Topical delivery ofhyaluronic acid into skin using SPACEpeptide carriers. J ControlRelease 173:67-74. 